\title{
The Pre and Post Effect of Covid-19 On India's Crude Oil Prices
}

\author{
Mrs. Ridhvika K Shetty ${ }^{1}$, Mrs. Divya M Shetty ${ }^{2}$ \\ ${ }^{1}$ Assistant Professor, Manel Srinivas Nayak Institute of Management, Bondel, Mangalore, Karnataka, India. \\ Email Id: ridhvikashetty@gmail.com \\ ${ }^{2}$ Assistant Professor, Manel Srinivas Nayak Institute of Management, Bondel, Mangalore, Karnataka, India. \\ Email Id: diviamshetty@gmail.com
}

\begin{tabular}{l} 
ABSTRACT \\
$\begin{array}{l}\text { Key Words: Million } \\
\text { barrels per } \\
\text { day(MMbpd), COVID, } \\
\text { crude oil OPEC, } \\
\text { Average returns, risk, } \\
\text { standard deviation, } \\
\text { pandemic }\end{array}$ \\
\hline
\end{tabular}

\section{Introduction}

The COVID-19 outbreak, which began in the Chinese city of Wuhan in November 2019, has been declared as a global pandemic on March 11, 2020 by the World Health Organization. COVID-19 has caused chaos on the world's financial markets, commodities markets, economic activities, employment, and GDP. While it is impossible to predict the exact economic impact of the global COVID-19 coronavirus pandemic, analysts believe that it will have significant negative consequences for the global economy.

Oil is both a raw material for industrial manufacture and a non renewable fossil fuel resource. Production, unemployment, inflation, trade, and the global economy are all affected by oil prices. And by the flow of global production levels, which can be influenced by wars, revolutions, OPEC decisions, financial issues, and the value of dollars. Crude oil prices are likely to be more volatile than those other energy sources. The rapid rise in virus cases around the world, along with the closure of international borders and the subsequent shutdown of all modes of transportation, has resulted in a major drop in demand for oil and fuel.

The purpose of this study is to see how COVID-19 impacted crude oil prices in India's economy. The Covid-19 epidemic which began in China at the end of 2019 and quickly expanded throughout the Far East, Europe, and North America by April 2020. Travel restrictions and national lockdowns reduced oil demand by 25-30 MMbpd between January and April 2020. (Million Barrels of oil per day). However, OPEC, led by Saudi Arabia, did not respond to this major drop in demand until May. In fact, Saudi Arabia "es crude oil production reached a peak of 11.9 MMbpd in April, an increase of 3 MMbpd. since January 2020 in the midst of the pandemic.The COVID-19 pandemic has grabbed everyone off guard, causing oil prices to crash to new lows. Due to increased economic uncertainty, several oil-exporting developing countries are seeing heightened capital outflows.

Data from Plats showed that India's diesel, gasoline and jet fuel consumption in the first half of May 2021 slumped 20 percent, 20 percent and 38 percent. US credit rating agency Moody's has reduced GDP growth forecast for India for 2021-22 to 9.3 percent 
from 13 percent earlier because of the economic impact of COVID-19, warning of pressure on the country's sovereign rating. The study's main goal is to determine the influence of Covid-19 on crude oil prices in India.

\section{Literature Review}

Vikas Barbate, Rajesh N. Gade, Shirish S. Raibagkar (2021) : The influence of COVID-19 on the Indian economy in the short and long term is examined in this article. The study reveals on the impact on the GDP growth rate to be least for the year 2020-2021. Unemployment and Inflation too is likely to rise in the short term at least. Base lending rate is expected to come down further as the government would like the banks to create more credit in the market. The industrial output is slated to take a strong beating in the year 2020-2021 .

Abdullah Alqahtani, Refk Selmi, Ouyang Hongbing, (2021) This study explores the responses of G20 stock markets to the COVID-induced plunge in oil price. The responses of G20 stock markets to the double blow of COVID-19 and the previous oil price shock are compared in this study. It examines the volatility spillovers between the spot price of crude oil and the stock markets during two separate periods with differing anxiety levels, namely the preand post-COVID-19 periods.

OZTURK, MBE, \& CAVDAR, SC (2021) This research examines the infectious effect of the COVID-19 pandemic on the volatility of chosen financial variables such as Bitcoin, gold, oil prices, and exchange rates, as well as the relationships between these variables' volatilities during the pandemic.

Pradeep Kumar Rangi, P. S. Aithal (2020): The study's findings suggest that asymmetric volatility in crude oil prices exists as a result of COVID-19 spread. The price volatility of crude oil is influenced by news about the spread of the COVID-19 epidemic. This research also points to the prospect of increased volatility in the future. The projected volatility of natural gas prices in the future is difficult to predict because the volatility graph is extremely volatile.

Monika Chaudhary, P. R. Sodani, Shankar Das (2020): This study focuses on assessing the impact on affected sectors, such as aviation, tourism, retail, capital markets, MSMEs, and oil. Study examines about the oil price which has plummeted to 18 -year low of $\$ 22$ per barrel in March, and Foreign Portfolio Investors (FPIs) withdrawn huge amounts from India, about USD 571.4 million. Article highlights how Rupee is continuously depreciating and difficulties faced by MSMEs which are under a severe cash crunch.

Raj, Vishal \& Bahl, Gitika. (2020). Coronavirus (COVID-19) and its Spillovers on Indian EconomyIn this paper, researcher discuss the impact of Coronavirus on various sectors of the economy, the financial market and analyse the situation by using some indicators like the GDP growth rate, unemployment rate, sectoral growth and loss in revenues etc. This paper mainly focuses on the situation in India during the crises to help understand the downturns and challenges faced by Indian Economy. Coronavirus (COVID-19) and its Spillovers on Indian Economy.

Meher, Iqbal ThonseHawaldar *, Latasha Mohapatra , Adel M. Sarea (2020) This research explores about the Impact of COVID-19 on Price Volatility of Crude Oil and Natural Gas Listed on Multi Commodity Exchange of India. It throws a light on the wide- spread demand and supply destruction and downward movement of crude oil prices is of concern for all those connected with the oil and gas industry. In this study, an attempt has been made to estimate the price volatility of crude oil and natural gas listed on multi commodity exchange of India (MCX). The findings of the study reveal that there is a presence of leverage effect of COVID-19 on the price volatility of crude oil.

Sarthak 0Agrawal, Kimran Khehra, Preksha Chopra (2018) This paper represents various 
fluctuations in crude oil prices within and outside India that have had an impact on the Indian stock market in general. Because the stock market is a speculative hub, it allows investors to game with stock prices and generate short-term gains and losses. However, crude oil, also known as liquid gold, has either made investors fly or cry.

Kemo SM Janka (2017) Crude oil is one of the crucial commodities in Indian economy, since the crude oil in India is not self-sufficient for consumption which trigger the country as the netimporter of crude oil this is due to high dependency of crude oil consumption in different sectors of the economy. In 2016 India imported 1.7Bn tons of crude oil. The study of this paper is based on yearly time series data from 2000 to 2016.This study has aim to find out the major determinants of crude oil price towards sustainable growth in India with this regards I used econometrics technique that is ordinary least squares method (OLS). This study finally concluded that the major factors that determine the crude oil price towards sustainable in India are OPEC crude oil price, import of crude oil, consumption of crude oil. All the above mentioned determinants are found significant individually likewise jointly.

Thiththalapitige Natasha Manieshi Fonseka, Moral Khan, Yawer Mushtaq Naik, Netanya Wondhar Khayi (2017) This The research focuses on how crude oil is the primary price determinant for all goods and services in a country, which is why individuals in a society are more concerned about crude oil price changes. On the other hand it studies how economists, policymakers, and governments all benefit from it.

Mr. Amee Gupta (2017) The purpose of this research study is to determine the function and impact of international crude oil and gold price changes on the Indian stock market (S\&P BSE SENSEX). This study was performed by collecting monthly data from London Bullion Market, U.S. Energy Information Administration, Bombay Stock Exchange (BSE) and BP StatisticalReview of World
Energy.

Abdulrahman Adnan Alqattan\& Ahmed Alhayky 2016) The effect of oil price turbulences in the stock markets was studied. There is a correlation between oil price and the stock markets in many oilproducing countries; this study tries to investigate this correlation in GCC countries as major oil producers and exporters. The study's goals are to assess the short and long-term effects of oil price changes in GCC nations, as well as the repercussions of stock market price changes as a result of oil price changes in GCC countries, and to look into the impact of stock price changes on GCC country local economies.

Narendra Punati, Ragavender Raju G (2016) This research has made an attempt to find out the major determinants of crude oil prices, for this purpose, they have employed the econometric technique i.e. ordinary least squares method. The study concluded that the determinants of crude oil prices (Brent crude oil prices, index of industrial production, exchange rate, and inflation) are found to significant.

\begin{abstract}
Akansha Sanjay Jain, Nitish Sunil Patil (2015) The fall in crude prices and the position of India's oil sector are empirically estimated in this article. It analyzes the relationship trend of production over its consumption and production with import. Then crude prices effect on India ${ }^{\text {ee }}$ s inflation, its importance to Reserve Bank of India, its impact on fiscal and tread deficit and Indian oil companies. Finally by considering all these effect and impacts we figure out future hold for India considering crude prices.
\end{abstract}

Geetanjali Narwal Nehra 2015 In this paper, an attempt has been made to study the impact of crude oil price on the Indian economy by considering Gross Domestic Product (GDP), Index of Industrial Production (IIP) and Wholesale Price Index (WPI) as the relevant variables. Crude oil is one of the highest demanded commodities in the entire world so fluctuations in crude oil price can make serious 
impact on the growth of any economy.

\section{:Objective of the Study}

1. To analyze the effects of the Covid outbreak on crude oil prices pre and post outbreak.

2. To evaluate the risk and return analysis of crude oil prices

\section{Need for the Study:}

Oil is a critical component in the manufacture of a wide range of goods and services. The study's main goal is to determine the influence of Covid-19 on crude oil prices in India. All those involved in the oil and gas business are concerned about the impact of COVID-19, which is a result of widespread demand and supply destruction and therefore a downward movement in crude oil prices. In this study, an attempt has been made to estimate the price volatility of crude oil listed on multi commodity exchange of

\section{Data Analysis And Interpretation:}

Table (1) Showing crude oil importing countries

\begin{tabular}{|l|c|c|}
\hline $\begin{array}{l}\text { Importing } \\
\text { countries }\end{array}$ & $\begin{array}{l}\text { Value (in } \\
\text { billion) }\end{array}$ & $\begin{array}{l}\text { \%o of overall } \\
\text { Imported } \\
\text { crudeoil }\end{array}$ \\
\hline China & 238.7 & $22.60 \%$ \\
\hline United states & 132.4 & $12.50 \%$ \\
\hline India & 102.3 & $9.70 \%$ \\
\hline Japan & 73.1 & $6.90 \%$ \\
\hline South Korea & 70.2 & $6.60 \%$ \\
\hline Netherlands & 46.4 & $4.40 \%$ \\
\hline Germany & 40.7 & $3.90 \%$ \\
\hline Spain & 30.5 & $2.90 \%$ \\
\hline Italy & 29.6 & $2.80 \%$ \\
\hline United Kingdom & 24.5 & $2.30 \%$ \\
\hline France & 24.4 & $2.30 \%$ \\
\hline Singapore & 24.2 & $2.30 \%$ \\
\hline Thailand & 22.3 & $2.10 \%$ \\
\hline Taiwan & 21.3 & $2 \%$ \\
\hline Belgium & 18.8 & $1.80 \%$ \\
\hline
\end{tabular}

India (MCX). Crude oil prices and profitability are significantly influenced by supply and demand. Due to a lack of crude in the domestic market, India has become dependent on another country as a result of rising consumption levels.

\section{Research Methodology:}

This study covers impact of Covid on crude oil price pre and post. Crude oil price volatility significantly influences the country's economy and also the commodity returns. Therefore understanding the demand and supply of crude oil price is an important issue from the perspective of a developing economy like India. The research by studying the risk and return analysis by the computation of average return $\&$ standard deviation. The price data is collected for six months prior to the pandemic and six months following the pandemic.
Graph (1) showing crude oil importing countries

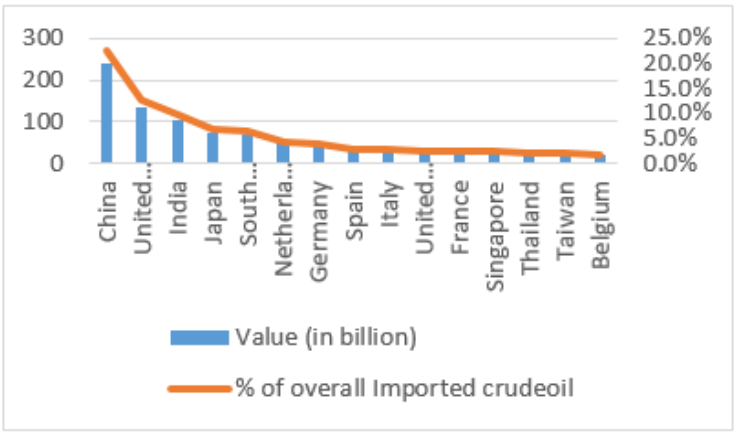

Table (2) Table showing crude oil imports into India

\begin{tabular}{|l|l|l|}
\hline Countries & $\begin{array}{l}\text { Value (in } \\
\text { billion) }\end{array}$ & $\begin{array}{l}\text { \% in the } \\
\text { value for } \\
\text { each } \\
\text { supplying } \\
\text { countries } \\
\text { since 2015 }\end{array}$ \\
\hline Iraq & 21 & $\begin{array}{l}\text { (Up 86.9\% } \\
\text { from 2015) }\end{array}$ \\
\hline Saudi Arabia & 20.5 & (Up 38.35\%) \\
\hline
\end{tabular}




\section{Available at: www.imperialpublications.com}

\begin{tabular}{|l|l|l|}
\hline $\begin{array}{l}\text { United Arab } \\
\text { Emirates }\end{array}$ & 9.9 & \multicolumn{1}{|c|}{ (Up 59.1\%) } \\
\hline Nigeria & 9.5 & (Up 2.4\%) \\
\hline Venezuela & 5.6 & $\begin{array}{l}\text { (Down - } \\
16.1 \%)\end{array}$ \\
\hline Kuwait & 5.1 & $(\mathrm{Up} \mathrm{11.4 \% )}$ \\
\hline United states & 4.5 & $(\mathrm{Up} \mathrm{28840 \% )}$ \\
\hline Mexico & 4.3 & $(\mathrm{Up} \mathrm{139 \% )}$ \\
\hline Iran & 3.5 & $\begin{array}{l}\text { (Down - } \\
15.8 \%)\end{array}$ \\
\hline Angola & 2.9 & $(\mathrm{Down}-6 \%)$ \\
\hline Malaysia & 1.8 & $(\mathrm{Up} \mathrm{24.3 \% )}$ \\
\hline Algeria & 1.51 & $(\mathrm{Up} \mathrm{599.7 \% )}$ \\
\hline Russia & 1.47 & $(\mathrm{UP} \mathrm{1967 \% )}$ \\
\hline Kazakhstan & 1.3 & $(\mathrm{Up} \mathrm{462.1 \% )}$ \\
\hline Qatar & 1.1 & $\begin{array}{l}\text { (Down- } \\
25.6 \%)\end{array}$ \\
\hline
\end{tabular}

\begin{tabular}{|c|c|c|}
\hline Brazil & 24 & $2.40 \%$ \\
\hline United Kingdom & 23.7 & $2.40 \%$ \\
\hline Mexico & 22.6 & $2.20 \%$ \\
\hline
\end{tabular}

Graph (3) Showing crude oil exporting countries

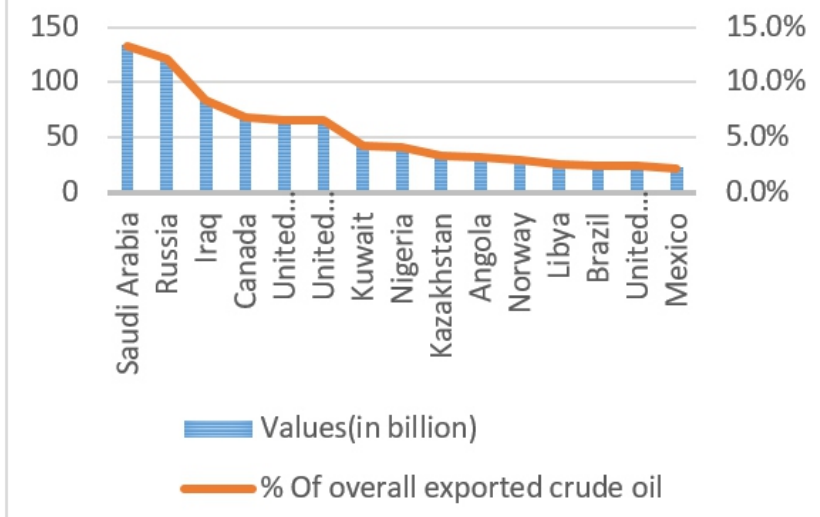

Table (4) Showing Risk and return analysis of crude oil before Covid outbreak

Graph (2) Showing crude oil importing countries

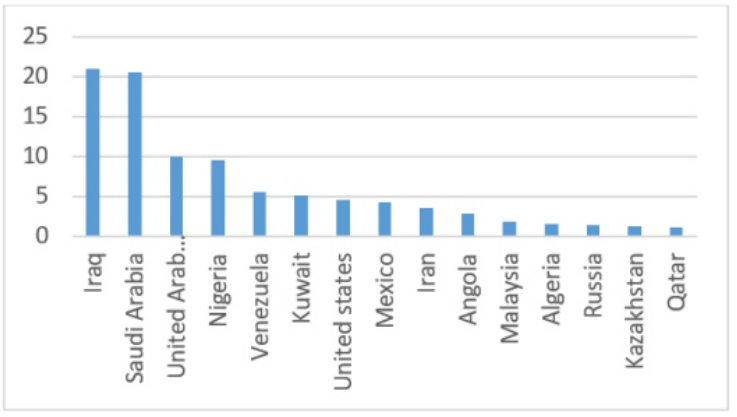

Table (3) Showing crude oil exporting countries

\begin{tabular}{|c|c|c|}
\hline Exporting countries & $\begin{array}{l}\text { Values(in } \\
\text { billion) }\end{array}$ & $\begin{array}{l}\text { \% Of overall } \\
\text { exported crude } \\
\text { oil }\end{array}$ \\
\hline Saudi Arabia & 133.6 & $13.30 \%$ \\
\hline Russia & 121.4 & $12.10 \%$ \\
\hline Iraq & 83.3 & $8.30 \%$ \\
\hline Canada & 68.1 & $6.80 \%$ \\
\hline United Arab Emirates & 66.1 & $6.60 \%$ \\
\hline United states & 65.3 & $6.50 \%$ \\
\hline Kuwait & 42 & $4.20 \%$ \\
\hline Nigeria & 41 & $4.10 \%$ \\
\hline Kazakhstan & 33.6 & $3.30 \%$ \\
\hline Angola & 32.3 & $3.20 \%$ \\
\hline Norway & 28.8 & $2.90 \%$ \\
\hline Libya & 24.8 & $2.50 \%$ \\
\hline
\end{tabular}

\begin{tabular}{|l|r|r|}
\hline \multicolumn{1}{|c|}{ Month(2019) } & $\begin{array}{l}\text { Average } \\
\text { Return }\end{array}$ & $\begin{array}{l}\text { Standard } \\
\text { deviation }\end{array}$ \\
\hline July & $-0.05 \%$ & $1.62 \%$ \\
\hline August & $0.24 \%$ & $2.51 \%$ \\
\hline September & $-0.01 \%$ & $4.08 \%$ \\
\hline
\end{tabular}

Graph (4) Chart showing Risk and return analysis of crude oil before Covid outbreak

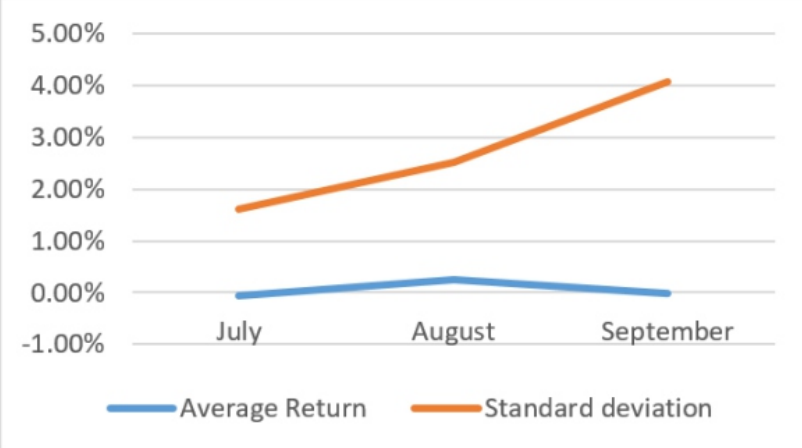

Interpretation: In the month July average return is negative value $-0.0543 \%$ which is very less compared to standard deviation i.e. $1.6152 \%$ the highest return for the month is $3.76 \%$. Returns are lower this month due to rising prices. In the month August standard deviation is $2.5114 \%$ which is has increased compared to last month. This means that while the risk of investing in crude oil is higher, the average return is also higher for month 
August is $0.2412 \%$, the highest return earned during this month of August is $5.30 \%$. In the month September standard deviation increased to $4.0774 \%$ and average return decreased to $-0.0094 \%$. September's risk rate is higher than the previous month's, however despite the high risk, on September 16th, the return was 15.45 percent as the crude oil price abruptly surged to Rs 4520 that day.

Table (5) Showing Risk and return analysis of crude oil before Covid outbreak

\begin{tabular}{|l|r|r|}
\hline \multicolumn{1}{|c|}{ Month (2019) } & $\begin{array}{l}\text { Average } \\
\text { Return }\end{array}$ & $\begin{array}{l}\text { Standard } \\
\text { deviation }\end{array}$ \\
\hline October & $-0.02 \%$ & $1.27 \%$ \\
\hline November & $0.17 \%$ & $1.79 \%$ \\
\hline December & $0.47 \%$ & $1.00 \%$ \\
\hline
\end{tabular}

Graph (5) Chart showing Risk and return analysis of crude oil before Covid outbreak

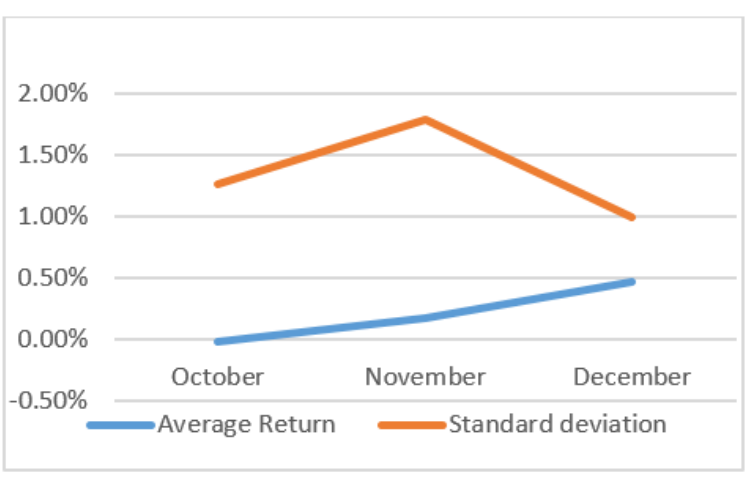

\section{Interpretation:}

In the month October standard deviation comes down to $1.2712 \%$ due to decrease in crude oil price. Highest return for the month is $2.49 \%$ Due to increase in crude oil prices average return for the month is $0.1708 \%$ which is high compared to average return of last month, risk being very low. And the in the end of the month i.e. on 29th November price suddenly decreased to Rs 3980. Highest daily return of the month is $2.91 \%$. In the month December average return is good i.e. $0.4686 \%$. in this month even though there is risk of $1.0049 \%$ the investor is earning good amount of profit. In this month highest daily return went up to $3.59 \%$. In this month's average return, the risk- adjusted return is favourable. The price began to fall at the end of the previous month, and it continues to fall this month, resulting in a positive monthly return.

Table (6) showing Risk and return analysis of crude oil after Covid outbreak

\begin{tabular}{|l|r|r|}
\hline $\begin{array}{c}\text { Month } \\
(\mathbf{2 0 2 0})\end{array}$ & $\begin{array}{l}\text { Average } \\
\text { Return }\end{array}$ & $\begin{array}{l}\text { Standard } \\
\text { deviation }\end{array}$ \\
\hline January & $-0.74 \%$ & $1.76 \%$ \\
\hline February & $-0.55 \%$ & $2.21 \%$ \\
\hline March & $-2.58 \%$ & $8.47 \%$ \\
\hline
\end{tabular}

Graph (6) Chart showing Risk and return analysis of crude oil after Covid outbreak

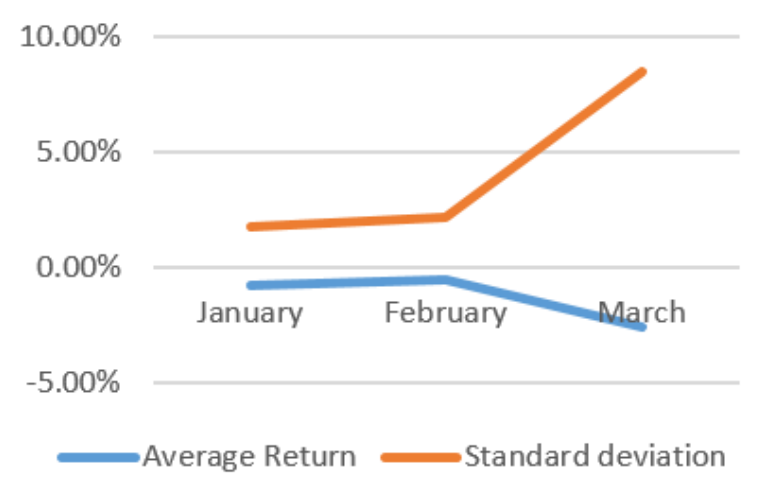

\section{Interpretation:}

The average return for the month of January is negative, i.e. -0.7410 percent, and the reason for this dip is that from the 22nd of January, Crude oil prices have begun to decrease, and individuals who bought crude oil last month may have incurred losses due to downfall in price, the highest return for the month is $3.59 \%$. In February prices starts falling because of which average return also declined to negative value i.e. $-0.5502 \%$ and also risk increased to $2.2137 \%$ compared to last month. The main cause for the market correction is the Covid- 19 outbreak Highest return for the month is $3.11 \%$. In the starting of month March prices are Rs 3431 after that at the end of the month it declined to Rs 1680. And the reason for this is slowdown in economic activities due to the pandemic. Hence there is negative return of $25845 \%$ and risk is very high i.e. $8.4737 \%$. 
Table (7) showing Risk and return analysis of crude oil after Covid outbreak

\begin{tabular}{|l|r|r|}
\hline \multicolumn{1}{|c|}{$\begin{array}{c}\text { Month } \\
\text { (2020) }\end{array}$} & $\begin{array}{l}\text { Average } \\
\text { Return }\end{array}$ & $\begin{array}{l}\text { Standard } \\
\text { deviation }\end{array}$ \\
\hline April & $0.44 \%$ & $19.03 \%$ \\
\hline May & $3.38 \%$ & $5.78 \%$ \\
\hline June & $0.79 \%$ & $3.02 \%$ \\
\hline
\end{tabular}

Graph (7) Chart showing Risk and return analysis of crude oil after Covid outbreak

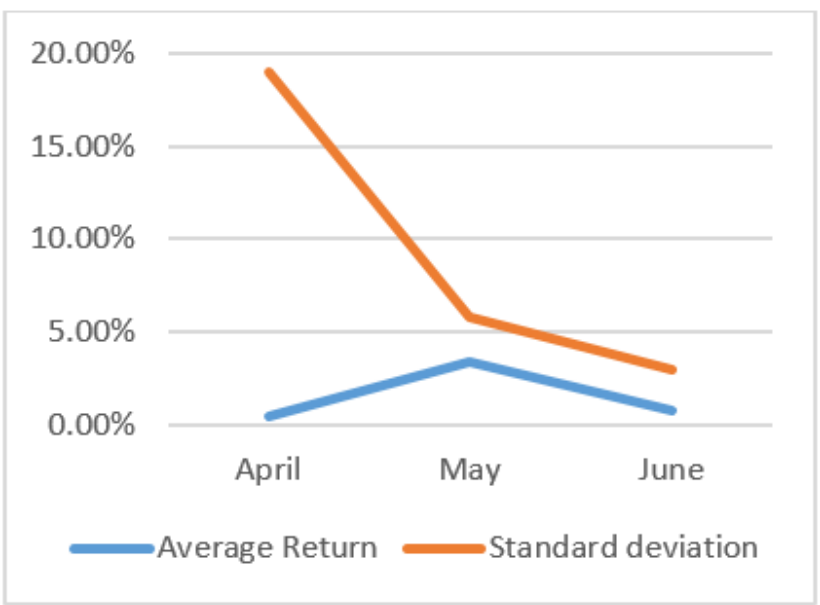

\section{Interpretation:}

In comparison to the previous month, prices are extremely low in the month of April., with a very high standard deviation of 19.0264 percent. Compared to last month average return for this month is high i.e. $0.4430 \%$ due to lack of demand and failure among oil-producing countries (Saudi Arabia and Russia). In the month of May there was a slight increase in the purchasing power due to which prices began to rebound, and the price of crude oil began to rise and also the average return of this month is increased to $3.3848 \%$. and risk also low compared to last month. The highest daily return for the month may is $20.19 \%$. A correction was seen in June due to which risk is more compared to return.

\section{Findings:}

- The decline in demand, combined with an unanticipated increase in supply, caused crude oil prices to plunge. Benchmark Brent crude oil prices have fallen almost 20 per cent to $\$ 55.14$ per barrel in a month.

- The Corona virus is having a significant impact on the global economy, as well as on the economic activities of individual countries. The coronavirus crisis has been devastating, and in March and April, prices slumped below zero with more than one billion surplus barrels. In other words, sellers were paying buyers to take deliveries to avoid storage cost.

- Oil prices are hovering around because to a lack of demand and a failure among oil-producing countries (Saudi Arabia and Russia) to agree on a production cut the oil prices are ruling in the range of \$27- 30 per barrel. That means savings of \$30-40 billion of annual savings for large oilimporting countries like India and China, this represents cost savings. This means that a significant amount of wealth will be shifted from oil-producing countries to oil-consuming countries over time.

- The government's limits on air travel have also had an influence on crude oil demand in India.

- The average citizen will not gain from lower crude oil prices, as the price of petrol and diesel did not decline. Despite a reduced Indian basket price, there is no demand for oil because to Covid-19, lockdown, restricted movement, and other factors.

\section{Suggestions:}

- India is one of the world's largest oil importers, importing roughly 84 percent of its domestic demand. Oil imports account for approximately a quarter of all imports in India. As a result, if oil prices decrease, the cost of importing oil from other countries will decline as well. As a result, the current account deficit is directly affected (the amount that India owes in foreign currency).

- Because of fall in the price of oil due to Covid-19 it helps in reducing the cost of importing from other country. But instead of depending on imports, they have to increase their exports by producing and refining crude oil in our home country.

- Ministry of Petroleum and Natural Gas should 
take several steps for promotion of renewable and alternate fuels like ethanol, second generation ethanol, compressed bio gas and biodiesel, promotion of natural gas as clean fuel/feedstock in the country with a view to move towards a gas based economy, refinery process improvements, promoting energy efficiency and conservation, efforts for increasing production of oil and natural gas.

- Using more energy efficient vehicles, such as hybrid and plug-in electric vehicles, is important for maintaining the successful trend of reducing crude oil imports.

\section{Conclusion:}

This study is based on impact of crude oil prices due to Covid-19 in India. The result of the study indicates that there is a presence of high volatility in crude oil prices due to the spread of Covid-19. This study includes Monthly risk and return analysis of crude oil prices, return and risk before and after covid outbreak.

Pre and post analysis of Covid -19 clearly tells that spreading of the pandemic Covid -19 has an impact on change in the crude oil prices. The risk measured in terms of standard deviation with crude oil prices is more after Covid outbreak i.e.6.542\% which is more compared to standard deviation of crude oil before Covid outbreak i.e.1.120\%. The six-month average return on crude was $0.132 \%$ before covid outbreak and $0.123 \%$ after covid outbreak. In conclusion, we can say that weak or reduced oil prices have a major negative impact on the Indian economy. Because India is a major importer of crude oil, increased oil prices necessitate larger payment in foreign currency. And oil prices have a significant impact on our country's financial markets. Crude oil derivatives used in the manufacturing of tyres represents $30 \%$ (synthetic rubber, carbon black, etc.) of the total raw material cost. A rise in crude oil prices would significantly impact the tyre manufacturing industry. With the global oil and gas industry still trying to figure out the full impact of the Corona virus on oil demand and economic growth,
Indian refiners are balancing inventory losses, dealing with reduced product cracks, and taking advantage of lower freight and spot shipment costs.

Bibliography:

Vikas Barbate, Rajesh N. Gade, Shirish S. Raibagkar (2021) COVID-19 and Its Impact on the Indian Economy Journal of health Management IIHMR Volume: 25 issue: 1, pp 23-35.

Abdullah Alqahtani, Refk Selmi, Ouyang Hongbing, (2021) The financial impacts of jump processes in the crude oil price: Evidence from G20 countries in the pre-and post-COVID-19, Resources Policy, Volume 72

OZTURK, MBE, \& CAVDAR, SC (2021). The Contagion of Covid-19 Pandemic on The Volatilities of International Crude Oil Prices, Gold, Exchange Rates and Bitcoin. The Journal of Asian Finance, Economics and Business, Vol 8 Issue 3,, pp 171-179

Pradeep Kumar Rangi, P. S. Aithal (2020) The Impact of COVID-19 on Price Volatility of Crude Oil and Natural Gas Listed on Multi Commodity Exchange of India International Journal of Management, Technology, and Social Sciences (IJMTS), Vol 10, Issue 5 pp 422-431

Monika Chaudhary, P. R. Sodani, Shankar Das (2020) Effect of COVID-19 on Economy in India: Some Reflections for Policy and Programme, Journal of health Management IIHMR, Vol 11, Issue 2, pp. 169-180

Mehta, Kamakshi and Jha, Shiv Swaroop, (2020) COVID19: A Nightmare for the Indian Economy.UGC Care Journal, Vol 31, Issue 20, pp 333-347

Raj, Vishal \& Bahl, Gitika. (2020). Coronavirus (COVID19) and its Spillovers on Indian Economy Conference: InternationaL online academic conference on the impact of the coronavirus COVID-19 on India 